\title{
Simulation of Baking Conditions and Start-Up of the Aluminium Electrolytic Cells and Their Effect on the Operating Performance of Cold Ramming Paste
}

\author{
Tatyana V. Butakova*a, \\ Elvira A. Zjulkovskayaa ${ }^{a}$, Grigoriy S. Bleskin ${ }^{a}$, \\ Alexey A. Spektoruk ${ }^{a}$ and Anatoliy V. Matveev \\ ${ }^{a}$ CJSC "ENERGOPROM - Novosibirsk Electrode Plant" \\ Novosibirsk Electrode Plant, Iskitimski district, \\ Novosibirsk region, 633216, Russia \\ ${ }^{b} L L C$ "ENERGOPROM R\&D Center" \\ 4 Lugovaya Str., bld. 7, SKOLKOVO, \\ Territory Innovation Centre, Moscow, 143026, Russia
}

Under study was the reaction of the basic operating performance of the cold low-shrinkage ramming paste (CRP) on the pre-heating conditions of the rammed joint. It was found out that the uncontrolled high-rate heat-up of the cold ramming paste (CRP) loosens the macrostructure and intensifies impregnation of the rammed layer.

The controlled delayed rate in the temperature rise of the inter-block joint up to $400{ }^{\circ} \mathrm{C}$ enables to obtain a high-quality layer of paste with the improved barrier properties against its impregnation with electrolyte.

Keywords: baking conditions, start-up of the electrolytic cell, rate in the temperature rise, inter-block joint, cold ramming paste, looseness of the macrostructure, impregnation with electrolyte.

Citation: Butakova T.V., Zjulkovskaya E.A., Bleskin G.S., Spektoruk A.A., Matveev A.V. Simulation of baking conditions and start-up of the aluminium electrolytic cells and their effect on the operating performance of cold ramming paste, J. Sib. Fed. Univ. Eng. technol., 2017, 10(7), 874-880. DOI: 10.17516/1999-494X-2017-10-7-874-880.

(C) Siberian Federal University. All rights reserved

* Corresponding author E-mail address: TButakowa@energoprom.ru 


\title{
Моделирование режимов обжига и пуска
}

\section{алюминиевых электролизеров и влияние}

\section{на эксплуатационные свойства холоднонабивной массы}

\author{
Т.В. Бутакова ${ }^{a}$ Э.А. Зюлковская \\ Г.С. Блескин ${ }^{\mathrm{a}}$, А.А. Спекторук ${ }^{\mathrm{a}}$, А.В. Матвеев ${ }^{\sigma}$ \\ аЗАО «ЭНЕРГОПРОМ-Новосибирский электродный завод» \\ Россия, 633216, Новосибирская область, Искитимский район, \\ промплощадка Новосибирского электродного завода \\ ${ }^{6} \mathrm{OОО} \mathrm{«НТЦ} \mathrm{группы} \mathrm{ЭНЕРГОПРОМ»}$ \\ Россия, 143026, Москва, территория Сколково \\ инновационного иентра, ул. Луговая, 4, стр. 7
}

Исследовалась реакиия основных эксплуатационных свойств массы холоднонабивной низкоусадочной МХНУ на режимы предварительного разогрева уплотненного шва. Установлено, что неконтролируемый высокоскоростной разогрев МХНУ разрыхляет макроструктуру и интенсифицирует пропитку уплотненного слоя.

Контролируемый замедленный темп подъема температуры межблочного шва до $400{ }^{\circ} \mathrm{C}$ позволяет получить качественный слой массы с улучшенными барьерными свойствами против пропитки электролитом.

Ключевые слова: режим обжига, пуск электролизеров, темп подъема температуры, межблочный шов, масса холоднонабивная, разрыхление макроструктуры, пропитка электролитом.

\section{Introduction}

Various customers of the bottom lining paste carry out the electrolytic cell heat-up and its preparation for the start-up in different ways; but the common thing is their striving for the final baking result - to exclude electrolyte and aluminum leakages to the edge and to the base lining of the cathode in the subsequent start-up period and throughout the entire life cycle. It means that, by the time of the electrolytic cell start-up it is necessary to generate a high-quality joint and achieve the full cohesion/bond of the joint body with the entire surface of the bottom and sidewall blocks (by length, height, in the inter-block joints and periphery joints around the cathode perimeter/ edges).

In some smelters, there is baking technology applied, according to which uniform and complete baking of the inter-block joints is performed, but hereby, heat-up of the periphery joint is effected with the indirect warmth via the heat transfer up to $50-100{ }^{\circ} \mathrm{C}$ in the volume and $200-220{ }^{\circ} \mathrm{C}$ on the surface. Similar approach to baking is based on the assumption that the raw and ductile periphery joint will not hinder the carbon material expansion in sodium in the subsequent start-up period, and herewith, will exclude the generation of the limitless stresses in the cathode blocks with their subsequent destruction.

On the one hand, the unlimited expansion of the furnace bottom should be avoided, but hereby, the controlled bottom reduction should be arranged just for the decrease of the possibility for cathode distruction; and it is obtained through the artificial compensation of the cathode blocks movement 
in the longitudinal and transversal directions being compressed by the lining elements. On the other hand, precariously uncontrolled, long-term existence of the periphery joint between 100-300 ${ }^{\circ} \mathrm{C}$ leads to absorption of the extra amount of the flowable binder into the adjoining surfaces of the bottom blocks, sidewall blocks and the edge material. As a result, the strictly balanced composition of the bottom paste is damaged; its operating performance is deteriorated.

The subsequent electrolytic cell start-up with the electrolyte pouring into the cathode shaft leads to a sharp temperature increase and coking/carbonization of the raw periphery joint at a high rate, even though it is covered with a layer of raw material. In fact, a volley surge of the volatile fractions of paste binder occurs, which is observable by "boiling" of electrolyte layer in the joint belt upon pouring the first vacuum-thimbles of electrolyte at start-up. Not only cohesion/bonding takes place, but also gaps between the sur-faces of the joint and block are formed. In addition, the joint body is loosened over the volume, dishardens, and loses its operating performance. It results in a significant increase of the possibility for generating of unfavorable outcomes - leakages of aluminium electrolyte and electrolyte underneath the bottom and emergency disconnection of the electrolytic cell.

To implement this or that scenario for the lifetime of the electrolytic cell overall, one may observe the initial development of the impregnation processes of the rammed layer of bottom paste in the laboratory conditions.

\section{Trial procedure}

For simulation of the rammed joint behavior, there were crucibles applied, manufactured from the different grades of blocks. The paste in the crucibles was compacted in the hydraulic press up to the layer height $\sim 40 \mathrm{~mm}$. Simulation of the conditions, in which the joint is in the electrolytic cell start-up period, was carried out in the shaft resistance oven. To perform this, the crucible with the compacted "green" or baked paste was being poured the melted electrolyte with $\mathrm{KO}=3$. The crucible was placed into the oven and soaked without electrolysis at $980^{\circ} \mathrm{C}$, within 10 or 120 minutes.

Upon completion of the trial and cooling, the crucibles were cut open in transversal direction to de-fine the character and intensity of impregnation with electrolyte in the model for the contact "joint-block". To identify electrolyte impregnation, one of the crucible transversal parts was wetted/ moisturized in the water. The impregnation developed after drying 12 hours later.

\section{Trial Results and their Discussion}

While pouring the electrolyte into the crucible on the raw compacted paste, intensive emission of the volatile fractions of the binder with their combustion occurs, i.e. explosive coking of the surface layers of the paste binder (CRP) (Fig. 1). After a 10-minute soaking in the oven, there was not discovered any system "crucible-compacted layer of paste" underneath the electrolyte of impregnation in the transversal direction (Fig. 2).

That is right, since during ingress of the melt on the cold surface of the paste, there is a crust of solid electrolyte formed.

However, the initial height of "green" ramming of $40 \mathrm{~mm}$ was increased up to $44 \mathrm{~mm}$, which amounts to a $10 \%$ - increase of the original volume, which is directly proportional to the increase of the pores volume, i.e. total porosity of the ramming body.

$$
-876-
$$




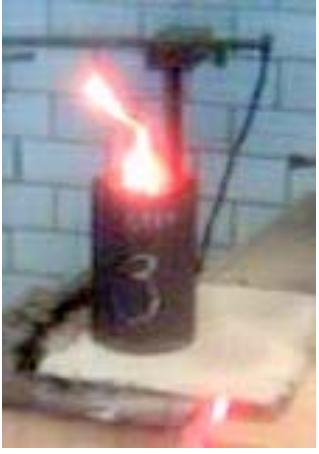

Fig. 1. Explosive coking of "green" paste

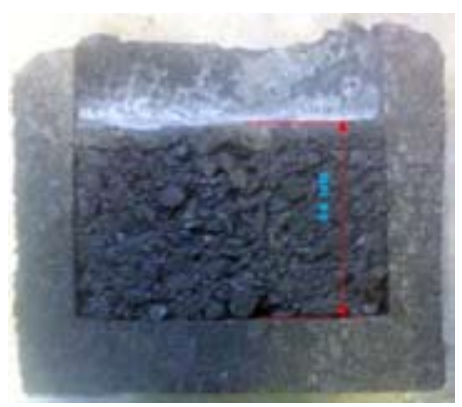

Fig. 2. Sample external looks after 10-minute trial
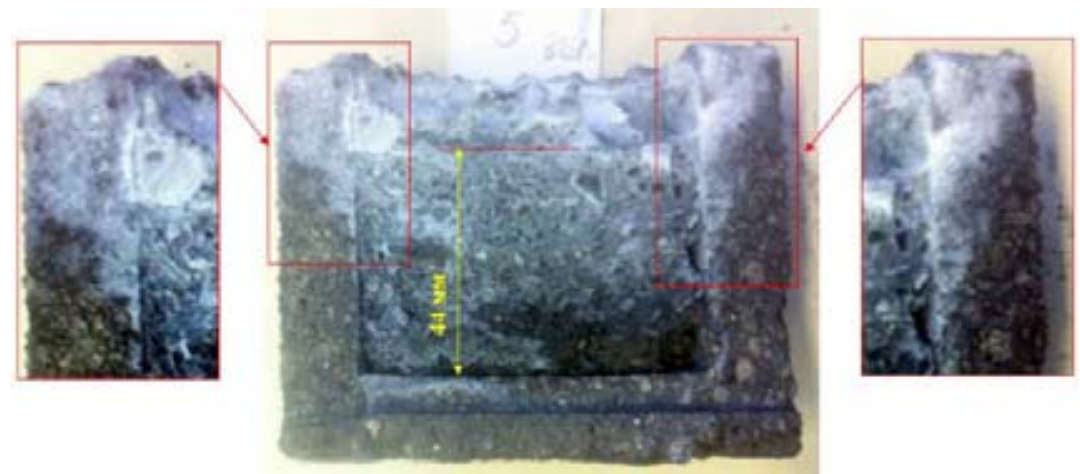

Fig. 3. Sample external looks after 120-minute trial

In another experiment with the "green" compacted layer of paste, only the duration of the soaking in the oven was altered up to 120 minutes at $980{ }^{\circ} \mathrm{C}$. The result of the trial is diametrically opposite - the paste impregnation throughout the height and the full volume of ramming is discovered (Fig. 3).

As well as in the previous experiment, (in the crucible with the 10-minute soaking in the oven) the loose macrostructure of the paste is observed. Impregnation runs through the compacted layer body and through the contact of the paste with the crucible side. With one of the sides (left in the Photo), the electrolyte penetration rate across the joint is higher. It means, that compactness of the contact "joint-block" around the perimeter of ramming is not uniform and uncontrolled, the final result and the place of impregnation (leakage spot)is only discovered after its development in the form of a breakthrough from the vessel (cathode shaft).

In the given experiment, the original volume increase of paste also amounted to $10 \%$. After the 2-hour soaking of the sample underneath the melts, porosity increased from 14,7 up to $18,2 \%$ or by $24 \%$ in relation to the previous sample with electrolyte pouring, but with the soaking at $980{ }^{\circ} \mathrm{C}$ within 10 minutes.

In another series of experiments, the target was set to define the effect of heating (baking) conditions of the samples on the impregnation rate of the ramming paste with electrolyte. An established baking curve was compared to the conditions that implied the primary heat-up period at a low rate up to 
$400{ }^{\circ} \mathrm{C}$ (Fig. 4). In that range, the basic operating characteristics of paste are formed/embedded expansion, subsequent shrinkage, density and hardness, which greatly depend on the intensity of the volatile fractions removal from the joint body.

Moreover, between $100-300{ }^{\circ} \mathrm{C}$, the flowable binder is fluid and can penetrate into the surface pores of the block. But for this, a long-lasting period of time is required, which is limited to 12 hours in that case. This limitation is needed in order to exclude "overdrying" of paste, i.e. to exclude excessive losses of binder.

For baking of the samples (crucibles with the compacted paste) underneath the coke breeze covering, a retort oven with the programmable heat-up conditions was used. After baking, electrolyte with aluminium (according to the established technique) was poured into the crucibles with the paste, the crucible with the melts were soaked in the ovens at $980{ }^{\circ} \mathrm{C}$ within 120 minutes. Upon the set time lapse, the crucibles were removed from the oven, the melt was poured out. After cooling, the crucibles were cut open in the transversal direction, one part of which was wetted/moisturized with water in order to develop the impregnation with electrolyte. The external looks of some samples and their impregnation parameters is shown in the Photo (Fig. 5) and Table 1 below.

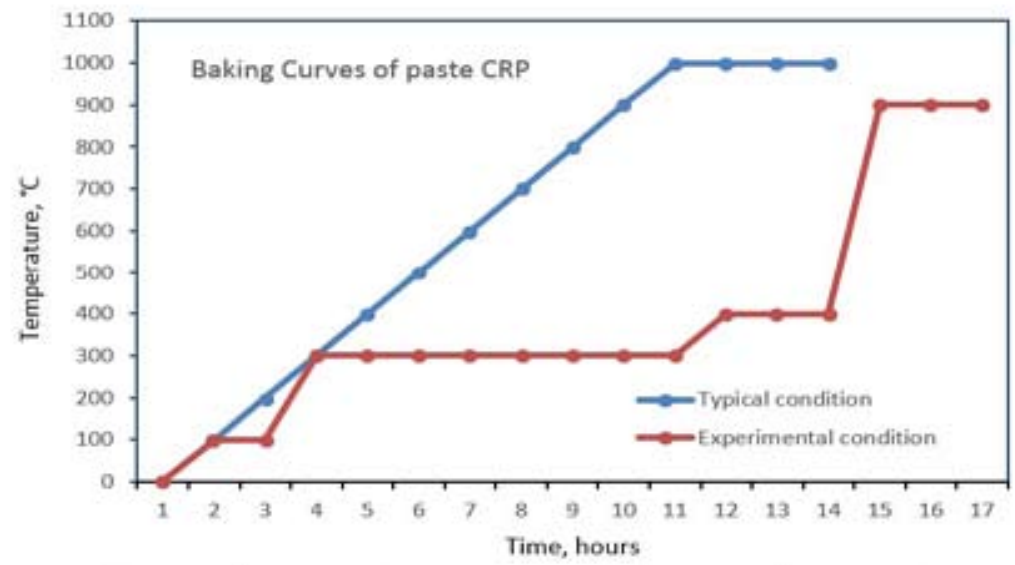

Fig. 4. Baking curves for cold low-shrinkage ramming paste samples (CRP)

Table 1. Comparative study results

\begin{tabular}{|c|c|c|c|c|c|}
\hline \multirow{2}{*}{ Item № } & \multirow{2}{*}{ Type (crucible) } & \multicolumn{2}{|c|}{ Sample № } & \multicolumn{2}{c|}{ Impregnation depth (H), mm } \\
\cline { 3 - 6 } & & 1 & 2 & 1 & 2 \\
\hline 1 & ECA-based & 8 & 11 & 26 & 23 \\
\hline 2 & ECA-based & 13 & 12 & 26 & 18 \\
\hline 3 & Graphite & 3 & 1 & 24 & 23 \\
\hline 4 & Graphite & 4 & 2 & 25 & 21,0 \\
\hline \multicolumn{7}{|c|}{ Mean values, mm } & 25,3 & 20,2 \\
\hline
\end{tabular}




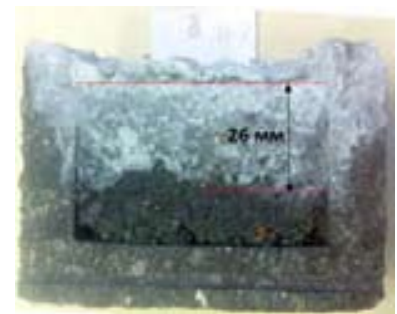

Sample № 8, block N-2.

Depth of impregnation $26 \mathrm{~mm}$

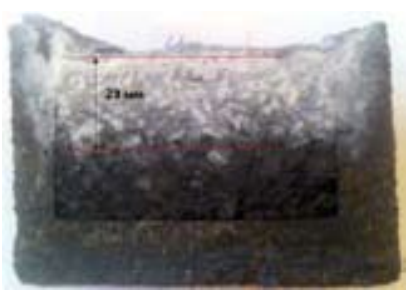

Sample № 11, block N-2. Depth of impregnation $23 \mathrm{~mm}$

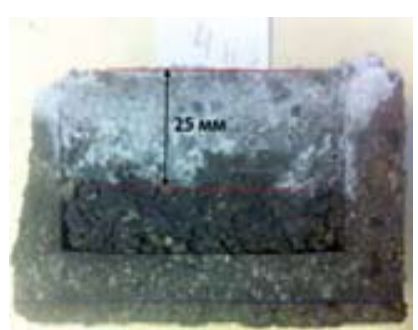

Sample № 4, block N-3.

Depth of impregnation $25 \mathrm{~mm}$

a

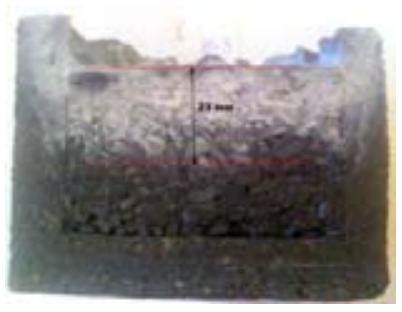

Sample № 1, block N-3.

Depth of impregnation $23 \mathrm{~mm}$

b

Fig. 5. The external looks of samples: $\mathrm{a}$ - established laboratory baking of cold ramming paste; $\mathrm{b}$ - experimental laboratory baking of cold low-shrinkage ramming paste

As it follows from the shown data, the samples impregnation depth baked at low rate in the initial stage of the heat-up, is lower by $20 \%$ compared to the baking conditions as per the established technology.

\section{Conclusions and recommendations}

1. Implementation of the high-rate heat-up of "green" cold ramming bottom paste of any type (for instance, with pouring of the electrolyte melt at the electrolytic cell start-up) leads to:

- A volley emission of the volatile fractions of the paste binder, which decreases the coking value of the binder in the joint body;

- A sharp increase of the paste volume and, as a consequence, looseness of the macrostructure, deterioration of the joint body characteristics (hardness decrease, density, porosity increase);

- Increase in impregnation rate of the joint with electrolyte;

- Deterioration of the cohesive/bonding conditions of the joint body with the blocks surface and in-crease in the penetration rate of electrolyte and aluminium in the contact "joint-block";

- Generating conditions for the uncontrolled leakages of the melt underneath the bottom, to the edge and the bloom windows - i.e. to generating of the emergency situation with the subsequent disconnection/shutdown of the electrolytic cell;

- Increase in the general overhaul costs/CAPEX and constrained/emergency non-value added down-time. 


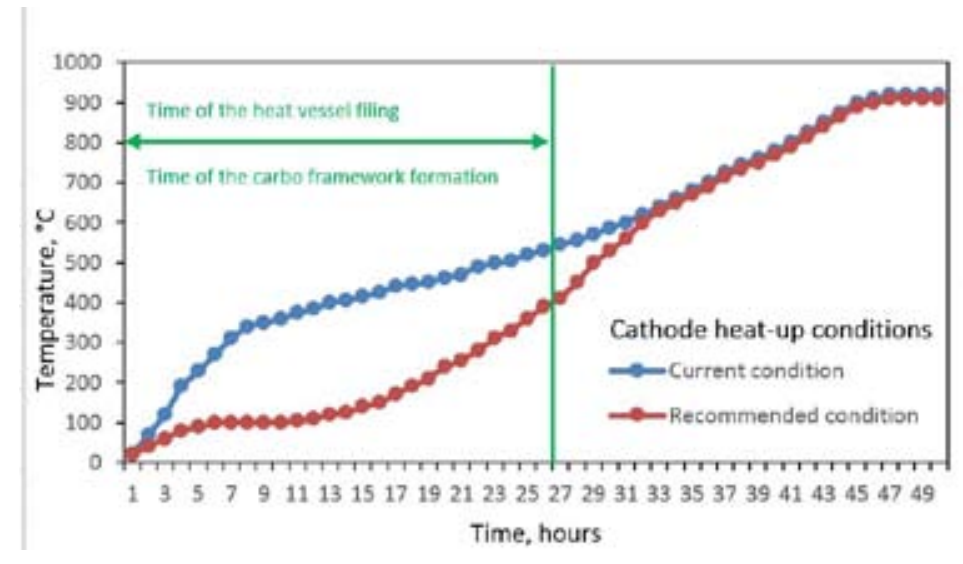

Fig. 6. Cathode heat-up conditions

2. The controlled delayed heat-up rate of the paste compacted layer at the original baking stage up to $400^{\circ} \mathrm{C}$, enables to improve the operating performance of the joint and its contact with the bottom block, significantly decrease the impregnation rate with electrolyte.

3. The results of the comparative experiment on the baking conditions of the bottom paste (CRP) are a cause for recommending the following heat-up curve of the electrolytic cell bottom (Fig. 6).

The recommended baking curve will enable to improve compaction quality from the cold low-shrinkage ramming paste (CRP), bonding/cohesion of the joint with the bottom blocks, decrease the intensity of the joints impregnation with electrolyte and possibility of the melt leakages underneath the bottom/hearth. 